find many. Only donor age and single versus bilateral lung transplantation were associated with long-term survival. It seems the risk imparted by donor/recipient characteristics at the time of transplant diminishes beyond the first year after transplant and becomes secondary to post-transplant determinants of graft function.

To understand the drivers of long-term survival, we should focus on the role of dynamic post-transplant events. These include the near universal episodes of rejection and infection, and over the long term immunosuppressionrelated renal dysfunction and diabetes. ${ }^{5}$ These dynamic post-transplant variables likely have greater impact on long-term survival than factors at the time of transplant. To improve long-term outcomes, we must establish evidence-based best practices for diagnosing and managing these events. For example, there is growing evidence that trends in spirometry post-transplant are associated with long-term survival. ${ }^{6,7}$ However, there is limited knowledge of how factors such as donor smoking, size mismatch, and gastroesophageal reflux disease affect spirometry trends. To better evaluate these dynamic post-transplant variables, individual center data may provide a more granular approach compared with large databases. Perhaps a multicenter study with granular evaluation of such characteristics could provide a more robust analysis.
Understanding the role that dynamic post-transplant variables play in long-term outcomes is essential to guide future studies and potentially uncover targeted interventions so we can make 10-year survival the norm and not the exception in lung transplantation.

\section{References}

1. OPTN/SRTR 2016 annual data report: introduction. Am J Transplant. 2018 18(Suppl 1):10-7.

2. Balsara KR, Krupnick AS, Bell JM, Khiabani A, Scavuzzo M, Hachem R, et al. A single-center experience of 1500 lung transplant patients. J Thorac Cardiovasc Surg. 2018;156:894-905.e3.

3. Yusen RD, Edwards LB, Kucheryavaya AY, Benden C, Dipchand AI, Dobbels F, et al. The registry of the International Society for Heart and Lung Transplantation: thirty-first adult lung and heart-lung transplant report-2014; focus theme: retransplantation. J Heart Lung Transplant. 2014;33:1009-24.

4. Jawitz OK, Raman V, Becerra D, Klapper J, Hartwig MG. Factors associated with short- vs long-term survival after lung transplant. J Thorac Cardiovasc Surg. 2022; 163:853-60.e2

5. Costa J, Benvenuto LJ, Sonett JR. Long-term outcomes and managemen of lung transplant recipients. Best Pract Res Clin Anaesthesiol. 2017;31: 285-97.

6. Belloli EA, Wang X, Murray S, Forrester G, Weyhing A, Lin J, et al. Longitudinal forced vital capacity monitoring as a prognostic adjunct after lung transplantation. Am J Respir Crit Care Med. 2015;192:209-18.

7. Mohanka MR, Kanade R, Garcia H, Mahan L, Bollineni S, Mullins J, et al Significance of best spirometry in the first year after bilateral lung transplantation: association with 3-year outcomes. Transplantation. 2020;104: 1712-9.

\title{
Commentary: Pleasure is bought at the price of pain
}

\section{Hiroshi Date, MD}

In this issue of the Journal, Jawitz and colleagues ${ }^{1}$ report a retrospective study using a large UNOS database to identify

\footnotetext{
From the Department of Thoracic Surgery, Graduate School of Medicine, Kyoto University, Kyoto, Japan.

Disclosures: The author reported no conflicts of interest.

The Journal policy requires editors and reviewers to disclose conflicts of interest and to decline handling or reviewing manuscripts for which they may have a conflict of interest. The editors and reviewers of this article have no conflicts of interest.

Received for publication Oct 25, 2020; revisions received Oct 25, 2020; accepted for publication Oct 26, 2020; available ahead of print Nov 5, 2020.

Address for reprints: Hiroshi Date, MD, Department of Thoracic Surgery, Graduate School of Medicine, Kyoto University, 54 Kawahara-cho, Shogoin, Sakyo-ku,

Kyoto 606-8507, Japan (E-mail: hdate@kuhp.kyoto-u.ac.jp).

J Thorac Cardiovasc Surg 2022;163:863-4

$0022-5223 / \$ 36.00$

Copyright (c) 2020 by The American Association for Thoracic Surgery

http://dx.doi.org/10.1016/j.jtcvs.2020.10.098
} 
factors associated with survival beyond a decade following lung transplantation. Factors independently associated with early mortality included donor black race, cigarette smoking, $\mathrm{PaO}_{2} / \mathrm{FiO}_{2}$ ratio, diabetes, recipient lung allocation score, total bilirubin, extracorporeal membrane oxygenation bridge requirement, single lung transplantation, and annual lung transplant center patient volume. Most of these risk factors for early death had been reported previously and are well known. ${ }^{2}$ The important and unique aspect of this study is the evaluation of risk factors associated with long-term survival among those patients who survived at least 1 year. Using adjusted logistic regression with the outcome of 10-year survival, the authors found that the only factors independently associated with long-term survival were donor age and single lung transplantation. Of note, most of the early risk factors, such as donor $\mathrm{PaO}_{2} / \mathrm{FiO}_{2}$ ratio and recipient lung allocation score, were not associated with long-term survival. The authors are to be congratulated for completing this important study.

Interpretation of the results of this study may differ among transplant centers. For example, should we avoid single lung transplantation, which was determined to be an independent risk factor in both the early and late phases? In some countries, such as Japan, a severe donor shortage and the risk of death while on the waiting list must be taken into consideration. ${ }^{3}$ As a result, more than one-half of our recipients have received single lung transplantation. The use of older donor lungs, with the risk of poor long term-survival, is also a difficult issue. Should we give old donor lungs to old recipients? Only to old recipients?

The most encouraging finding of this study is the disagreement of early and late risk factors. In other words, recipients receiving high-risk lung transplantation may live long once they survive stormy early postoperative period. It is like "pleasure is bought at the price of pain."

\section{References}

1. Jawitz OK, Raman V, Becerra D, Klapper J, Hartwig MG. Factors associated with short- versus long-term survival after lung transplant. J Thorac Cardiovasc Surg. 2022; 163:853-60.e2.

2. Chambers DC, Yusen RD, Cherikh WS, Goldfarb SB, Kucheryavaya AY, Khusch K, et al. The Registry of the International Society for Heart and Lung Transplantation: thirty-fourth adult lung and heart-lung transplantation report2017; focus theme: allograft ischemic time. J Heart Lung Transplant. 2017;36: 1047-59.

3. Date H. Current status and problems of lung transplantation in Japan. J Thorac Dis. 2016;8(Suppl 8):S631-6. 